\title{
Effective Usage of Information and Communications Technology by Career Administrators in Tertiary Institutions: The Obafemi Awolowo University Experience
}

\author{
POPOOLA O. Olufemi, Ph.D SEGUN-OLASANMI Adeduntan O. \\ Department of Public Administration, Obafemi Awolowo University, Ile-Ife, Nigeria
}

\begin{abstract}
The study identified the information and communication technology tools used by career administrators in Obafemi Awolowo University, Ile-Ife; determined the level of ICT compliance in the performance of administrative tasks by the career administrators in the said institution; examined the attitude of the respondents to the adoption and use of information and communication technologies in performing administrative tasks; and identified the challenges militating against the optimum deployment of information and communication technologies by career administrators in the institution under reference. These were with the view to understanding the use of information and communication technologies by professional or career Administrators in the study area. Both primary and secondary data sources of data collection were employed for the study. The former were obtained through a structured questionnaire and complemented by an interview guide. Out of a study population of 109, 85 respondents were selected by a simple random technique. Secondary data were obtained from relevant university books and digests, previously published and unpublished studies related to the use of ICT in different sectors of national life, official documents and internet sources on ICT. Data collected were analyzed using simple percentages. The study showed that access to basic ICT hardware such as desktop computers (85.8\%) and printers $(77.6 \%)$ in the workplace was fairly adequate, though, usage had to be negotiated in some instances. $92.9 \%$ of the respondents were able to use Microsoft Word and 5\% were able to use Microsoft Access, while only $1.2 \%$ each were able to deploy the use of Prezi and Evernote in providing administrative services. The study also revealed that the major challenges militating against the maximal deployment of ICT tools by the respondents are epileptic power supply, unstable internet connectivity and the need to have to negotiate with other users of ICT hardware such as desktop, laptops and scanners in the workplace, before gaining access to such tools. The study concluded that information and communication technologies have been widely embraced by career Administrators in the University and this has to a large extent improved effectiveness, accuracy and efficiency in the area of service delivery. However, there was need for further training especially with regards to the use of some software with advanced features in Microsoft Word as well as Power Point, Prezi, Evernote, and Microsoft Access for improved administrative services in the University.
\end{abstract}

Keywords: Information and Communications Technology; Higher Education Administration, Career Administrators, Prezi, Evernote

DOI: $10.7176 / \mathrm{JESD} / 10-16-21$

Publication date: August $31^{\text {st }} 2019$

\section{Introduction}

The turn of the current millennium witnessed an unprecedented revolution in the world of Information and Communication Technologies (ICTs). Before the $21^{\text {st }}$ century, the history of information technology had been divided into three phases, which were the Pre-mechanical, Mechanical and Electromechanical phases. The electronic age which we currently live in has affected virtually all facets of life, both private and public. At individual and household levels, smart phones, mobile hotspots, use of modems, kindles and iPads, to mention a few, have become a prominent feature. Business organizations, corporations, educational and financial institutions are not left out in the Information Technology (IT) revolution. Office-related procedures and processes such as job applications, recruitment, selection, appraisal, accounting, etc, have recently assumed a digital dimension as against the manual and much strenuous methods previously used.

Public institutions, including Universities, have also embraced the information technology revolution and this has dramatically altered the landscape of activities in such Institutions. For instance, the current teaching methods employed by University lecturers are largely information technology-driven. In highly developed climes, lecturers give their lectures without physically appearing in class. Students are also able to have a similar experience. Here in Africa, the use of projectors, screens and amplifiers are some of the ways in which the usage of information and communication technology tools has been embraced in such academic environments. Similarly, the process of recruiting new staff, which used to be by submitting a hand-written application letter and attending an oral interview with or without a prior written examination, has taken a digital turn. In recent times, potential employees have had to submit typed application letters using appropriate word processors such as Microsoft, as against the hand-written ones. The norm today is to fill an application form online, on the website of the company or institution 
handling the recruitment and upload all credentials within a specified time frame. In addition to that, interviews can be conducted from any part of the world via telephone, skype or video-conferencing.

The role of Career Administrators in enhancing smooth administration of higher education institutions, particularly, universities, cannot be over-emphasized. Some of the areas where they provide such services are screening of fresh students, provision of accommodation, processing of results, generation of transcripts for graduated students, recruitment, orientation and promotion of staff, servicing of statutory and ad-hoc meetings, preservation of Institution records, etc. Traditionally, Career Administrators used to operate mainly with files and paper. These were the major tools in covering meetings and providing other support services for the smooth running of the University enterprise.

However, University administration has become much more complex in the last couple of decades. Universities have been highly proliferated in terms of numbers and students' enrolment has increased, with attendant consequences such as increase in the number of staff also. Many more programmes have found their way into school curricula in order to take care of a wide range of students' needs. Examples of such are Executive Masters' programmes, Distance Learning programmes, etc. Consequently, administrative processes have had to step up to provide commensurate speed and accuracy for facilitating academic teaching, learning and research.

The need for effective administration is further strengthened by the fact that stability of the University Calendar is highly threatened in a vast number of Nigerian universities. The reasons adduced for this are quite multivariate. Students' rampages, staff (industrial relations) conflict and strike actions as well as national problems are just a few of such reasons. More often than not, the University Calendar gets altered in the course of the academic session to accommodate all these instabilities and changes. In order to make the best use of available time and optimize productivity, efficiency and effectiveness therefore, academic and administrative procedures need to be streamlined using modern tools for best results.

This study therefore addressed the objectives of identifying the information and communication technology tools used by career administrators in Obafemi Awolowo University, Ile-Ife; determining the level of ICT compliance in the performance of administrative tasks by the career administrators in the said institution; examining the attitude of the respondents to the adoption and use of information and communication technologies in performing administrative tasks; and identifying the challenges militating against the optimum deployment of information and communication technologies by career administrators in the institution under reference.

\section{Literature Review and Conceptual Clarifications}

Information and Communication technologies consist of a complex and heterogeneous set of goods, services and applications, which are used to acquire, store, process, retrieve and transmit information in an accurate and timely manner. It is practically the epicenter of every aspect of life and living in the new millennium (Ogunruku, 2012). It also refers to diverse sets of technological tools and resources used to communicate, and to create, disseminate, store, and manage information.

The role of ICT in the development of national life has come to fore more than ever before in the last decade. In small, large, private and public organizations, ICT plays significant roles in facilitating efficient and effective ways of ensuring sustainable development. In the year 2000, the Economic and Social Council adopted a Ministerial Declaration on the role of information technology in the context of a knowledge-based economy (UNESCO, 2000).

Subsequently, a high level information and communications technologies task force was established to provide overall leadership to the United Nations on the formulation of strategies for the deployment of ICT in order to foster development (UN, 2002). Reinforcing this assertion, Popoola (2013) declared that Information Communication Technology remains one important engine for sustainable socio-economic development across the globe. This has stimulated a policy initiative in the direction of harnessing and deploying information communication technologies to address emerging issues in countries under the umbrella of the United Nations. Sectors such as Education, Health, Security, Industry, etc, are all embracing the modern trends in deployment of information and communication technology, to accelerate societal development. In the area of educational services, especially in ntertiary institutions, Information Communication Technology has become a sine-qua-non.

The World Education Report of UNESCO (1998) noted that education in its global dimensions had been facing a lot of challenges in preparing students and teachers for "our future 'knowledge-based' society" during a time when most teachers are not prepared to use ICT and "the majority of existing school buildings, even in the most developed countries, are not equipped to integrate the new information and communication technologies." Today, ICT in education encompasses a wide range of rapidly evolving technologies such as desktop, notebook, and handheld computers; digital cameras; local area networking; the Internet and the World Wide Web; CD-ROMs and DVDs; and other applications such as word processors, spreadsheets, tutorials, simulations, electronic mail (E-mail), digital libraries, computer-mediated conferencing, video-conferencing, and virtual reality.

Breach (1975) defined "Administration" as the part of management process concerned with the installation and execution of procedures by which programmes, plans and targets are laid down and communicated, and the 
progress of activities regulated and checked against them. Administration sub-systems in a higher education setting are of a complex nature due to the diverse units and departments that are involved. The sub-systems include personnel administration, students' administration, resources administration and financial administration. As far back as 2003, Ojedokun and Owolabi posited that teachers in the developing world would have to change their teaching styles and acquire Internet skills as new technologies transform classrooms over the next 20 years. Not only has this been found to be true of teachers and students, administrators of the higher education enterprise have also been confronted with the need to upgrade their skills in order to cope with the new technologies that dominate the higher education milieu in this century.

According to Salerno (2009), there are several ways of introducing information and communication technology in the administration of higher education institutions. Some of them are: sending notices of meetings electronically rather than printing and distributing them, insisting that teachers or lecturers create class Web pages, ensuring that academic staff submit lesson plans online, making provision for insertion of e-mail addresses on the forms that parents and guardians fill, admissions through web-enabled processes, etc. As noted by Bello \& Aderibigbe (2014), ICT has become a veritable tool in extending educational opportunities through the creation of pathways for increased access to previously under-served constituencies by collaborative, integrative, active and creative learning systems. These include distant learning opportunities, Open University systems, creation of regular and executive modes of study to accommodate students who are also working full-time and who have highly restricted hours to improve themselves academically, etc.

\section{Methodology}

Career Administrators in the Obafemi Awolowo University, Ile-Ife, constituted the study population. Out of a total of 109 Administrators, 85 respondents were selected through a simple random technique to constitute the sample size. Copies of the questionnaire administered to the respondents were in three major sections. The first section covered the socio-demographic and personal details of respondents such as gender, age range, marital status, highest education obtained and nature of academic background.

In the second section, information on the professional details of respondents such as rank, number of years in the service of the university, status on assumption of duty, length of administrative career and present posting were elicited through the questionnaire. The third section focuses on the usage of information and communication technology tools by respondents through the identification of the tools or hardware provided officially and those owned personally as well as software that respondents were able to operate in the course of discharging their administrative duties. The attitude of the respondents to training for increase in ICT proficiency was also examined. All the questions were configured along the lines of the objectives of the study. In addition, structured interview guides were administered on 5 very senior Administrators at the level of Director, to complement information elicited through the questionnaire.

The data collected were analysed using the Standard Statistical Package for Social Science research (SPSS) to generate frequency distribution, simple percentages and bar charts. Further tests to determine association of key variables with factors such as access to ICT tools, ownership of ICT tools and use of ICT software by respondents were carried out and measured by chi-square values.

\section{Results}

\section{Socio-Demographic Description of Respondents}

From the data collected, $56.5 \%(n=48)$ of respondents were male while $43.5 \%(n=37)$ were female. Also, $95.3 \%$ of respondents were aged between 31 and 60 years, which implies that majority of members of staff in the administrative officers' cadre were in the peak productive years of the average working class person.

Results also showed that Career Administrators at Obafemi Awolowo University were educated with at least a first degree, which is the minimum level to secure employment into the Administrative Officers' cadre. 25\% of the respondents had Masters Degree by research, while 37\% had acquired professional Masters Degrees. Only a few $(2.4 \%)$ of the respondents had Doctors of Philosophy (Ph. D) degrees. A few indicated that they had commenced their $\mathrm{Ph}$. D programmes some years back but were yet to complete them for lack of adequate administrative support. From the results, it can be inferred that Career Administrators at Obafemi Awolowo University appreciated the value of knowledge and sought to pursue it to the highest level possible.

The study further showed that almost half of the respondents were from the Arts / Humanities background in disciplines such as English, History, Philosophy, and Religious Studies, among others. 20\% of the respondents were educated in the Social Sciences disciplines, while $16.5 \%$ were trained as scientists. $7.1 \%$ had legal background training while others were from the fields of Education, Business Administration and Engineering. It was therefore clear from the study that the Career Administrators at Obafemi Awolowo University were of a good mix of different disciplines and there was no restriction to recruitment based on course of study. This is typical of an ideal public administration setting in the sense that it demonstrates the eclectic nature of public administration. 
Results from Data obtained through Questionnaire

Objective 1: identify the Information and Communication Technology tools used by Career Administrators in Obafemi Awolowo University, Ile-Ife

Table 1: Frequency Distribution of Respondents according to Access to ICT tools, Ownership of ICT tools and ability to use ICT software

\begin{tabular}{|c|c|c|c|c|c|c|c|c|c|c|c|c|}
\hline \multirow{2}{*}{$\begin{array}{l}\text { Access to ICT tools in the work } \\
\text { place }\end{array}$} & \multicolumn{2}{|r|}{$\mathbf{S A}$} & \multicolumn{2}{|r|}{$\mathbf{A}$} & \multicolumn{2}{|c|}{$\mathbf{U}$} & \multicolumn{2}{|r|}{$\mathbf{D}$} & \multicolumn{2}{|r|}{ S D } & \multicolumn{2}{|r|}{ Total } \\
\hline & f & $\%$ & $\mathbf{F}$ & $\%$ & $\mathbf{f}$ & $\%$ & $\mathbf{f}$ & $\%$ & $\mathbf{f}$ & $\%$ & $\mathbf{f}$ & $\%$ \\
\hline Desktop computer & 45 & 52.9 & 28 & 32.9 & 5 & 5.9 & 5 & 5.9 & 2 & 2.4 & 85 & 100.0 \\
\hline Laptop computer & 30 & 35.3 & 25 & 29.4 & 3 & 3.5 & 15 & 17.6 & 12 & 14.2 & 85 & 100.0 \\
\hline Internet facilities & 17 & 20.1 & 22 & 25.8 & 0 & 0.0 & 30 & 35.3 & 16 & 18.8 & 85 & 100.0 \\
\hline $\begin{array}{l}\text { Official e-mail username and } \\
\text { password }\end{array}$ & 39 & 34.1 & 28 & 32.9 & 11 & 13.0 & 9 & 10.6 & 14 & 16.5 & 85 & 100.0 \\
\hline Printer & 37 & 43.5 & 29 & 34.1 & 4 & 4.7 & 8 & 9.4 & 7 & 8.2 & 85 & 100.0 \\
\hline Scanner & 4 & 4.7 & 7 & 8.2 & 0 & 0.0 & 27 & 31.8 & 47 & 55.3 & 85 & 100.0 \\
\hline Flash drive & 37 & 43.5 & 26 & 30.6 & 7 & 8.2 & 10 & 11.7 & 5 & 5.9 & 85 & 100.0 \\
\hline Projector & 2 & 2.4 & 3 & 3.5 & 0 & 0.0 & 35 & 41.2 & 45 & 52.9 & 85 & 100.0 \\
\hline Fax machine & 0 & 0.0 & 0 & 0.0 & 0 & 0.0 & 0 & 0.0 & 0 & 0.0 & 85 & 100.0 \\
\hline \multicolumn{13}{|l|}{ Personal ownership of ICT tools } \\
\hline $\begin{array}{l}\text { Smart phone enabled for } \\
\text { administrative and internet } \\
\text { functions }\end{array}$ & 47 & 55.3 & 17 & 20.0 & 6 & 7.1 & 4 & 4.7 & 11 & 12.9 & 85 & 100.0 \\
\hline Kindle & 1 & 1.2 & 0 & 0.0 & 0 & 0.0 & 32 & 37.6 & 52 & 61.2 & 85 & 100.0 \\
\hline Desktop computer & 20 & 23.5 & 12 & 14.1 & 19 & 22.4 & 20 & 23.5 & 14 & 16.5 & 85 & 100.0 \\
\hline Laptop computer & 44 & 51.8 & 20 & 23.5 & 8 & 9.5 & 7 & 8.2 & 6 & 7.1 & 85 & 100.0 \\
\hline Tablet & 22 & 25.9 & 12 & 14.1 & 7 & 8.2 & 20 & 23.5 & 24 & 28.3 & 85 & 100.0 \\
\hline Ipad & 21 & 24.7 & 16 & 18.9 & 20 & 23.5 & 15 & 17.6 & 13 & 15.3 & 85 & 100.0 \\
\hline Flash drive & 52 & 61.2 & 13 & 15.3 & 2 & 2.4 & 12 & 14.1 & 6 & 7.1 & 85 & 100.0 \\
\hline Printer & 3 & 3.5 & 4 & 4.7 & 0 & 0.0 & 27 & 31.8 & 51 & 60.0 & 85 & 100.0 \\
\hline Projector & 0 & 0.0 & 1 & 1.2 & 0 & 0.0 & 30 & 35.3 & 54 & 63.5 & 85 & 100.0 \\
\hline $\begin{array}{l}\text { Internet facilities (modem based or } \\
\text { data-enabled) }\end{array}$ & 36 & 42.4 & 12 & 14.1 & 18 & 21.1 & 8 & 9.4 & 11 & 12.9 & 85 & 100.0 \\
\hline \multicolumn{13}{|l|}{ Ability to operate ICT software } \\
\hline Microsoft Word & 57 & 67.1 & 22 & 25.9 & 2 & 2.4 & 2 & 2.4 & 2 & 2.4 & 85 & 100.0 \\
\hline Microsoft Excel & 12 & 14.1 & 13 & 15.3 & 0 & 0.0 & 10 & 11.7 & 45 & 52.9 & 85 & 100.0 \\
\hline Microsoft Power Point & 10 & 11.8 & 11 & 12.9 & 9 & 10.6 & 51 & 60.0 & 4 & 4.7 & 85 & 100.0 \\
\hline Prezi & 1 & 1.2 & 0 & 0.0 & 0 & 0.0 & 84 & 98.8 & 0 & 0.0 & 85 & 100.0 \\
\hline Evernote & 1 & 1.2 & 0 & 0.0 & 0.0 & 0.0 & 84 & 98.8 & 0 & 0.0 & 85 & 100.0 \\
\hline Microsoft Access & 0 & 0.0 & 4 & 4.7 & 0 & 0.0 & 0 & 0.0 & 81 & 95.3 & 85 & 100.0 \\
\hline
\end{tabular}

Source: Field Survey

The data presented in the table above centre majorly on the access of the respondents to ICT hardware in the workplace, their ownership of some ICT hardware and their ability to use some ICT software. The study revealed that $85.8 \%$ and $64.7 \%$ of respondents had access to desktop and laptop computers respectively, in their offices. Further interaction with these respondents showed that the access was not always in their personal offices and could be in the general office of their Department or Unit. In the same vein, they sometimes had to bargain or negotiate with other users to get a time slot for using the desktop computers especially. Also, while $61.2 \%$ reported that they were registered with official usernames and passwords, only $33.0 \%$ reported that they had access to internet facilities in the office. This implies that the availability of internet facilities did not match the number of people that were willing to use it as demonstrated by their registering for it.

Most of the respondents had access to printers and flash drives in their offices by a representation of $77.6 \%$ and $74.2 \%$ respectively. However, those that had access to scanners and projectors were in the minority and represented $7.1 \%$ and $3.5 \%$ respectively. None of the respondents had access to a fax machine. This could be because fax machines were usually used in conjunction with landline telephones which had become rather obsolete with the advent of the GSM / mobile phone. Also, the internet provided a faster means of international communication than the fax machine, which in most cases was not even available.

In terms of ownership of ICT tools, $75.3 \%$ of the respondents had personal smart phones that were enabled to perform administrative functions with or without links to the internet. Some of the administrative functions performed on their smart phones were sending text messages, e-mails, notices of meeting, etc. Some respondents also reported that they used their smart phones to take audio and video recordings of proceedings of meetings. The 
percentage of respondents that owned laptop computers far outweighed those with desktop computers in a 2:1 ratio $(75.3 \%$ to $37.6 \%)$ while those who owned Tablets and iPads were about the same number.

The study also elicited information on the ability of the respondents to use a variety of ICT tools. Results showed that about $93 \%$ of the respondents were able to use Microsoft Word in varying degrees. On the other hand, the percentages of those who were able to use Microsoft Excel and Microsoft Power point were 14.2\% and 11.8\% respectively while only $1.2 \%$ had the ability to use Prezi and Evernote applications. By implication, Career Administrators at Obafemi Awolowo University were most proficient in word processing applications while they were largely deficient in the use of spreadsheet and data base applications. The study further revealed that Microsoft Word was the most used ICT software and that a strong association was found to exist between access to ICT and job rank of respondents with more highly ranked Administrators having higher access to ICT facilities $(\mathrm{p}$ value $=0.001 ; \mathrm{df}=6)$.

The next section provides information on the percentages of the respondents that deployed ICT, manual, verbal and a combination of both ICT and manual tools in the performance of administrative tasks. This is with a view to determining the level of ICT compliance of Career Administrators at Obafemi Awolowo University in the discharge of their administrative duties.

Objective 2: determine the level of ICT compliance in the performance of administrative tasks by Career Administrators in Obafemi Awolowo University, Ile-Ife

Table 2: Frequency Distribution of Respondents showing the level of ICT compliance in the performance of administrative duties

\begin{tabular}{|c|c|c|c|c|c|c|c|c|c|}
\hline \multirow[t]{3}{*}{$\mathbf{S} / \mathbf{N}$} & \multirow[t]{3}{*}{ Administrative Tasks } & \multicolumn{8}{|c|}{ Type of tools employed } \\
\hline & & \multicolumn{2}{|r|}{ ICT } & \multicolumn{2}{|c|}{ Manual } & \multicolumn{2}{|c|}{ Verbal } & \multicolumn{2}{|c|}{$\begin{array}{r}\text { Both ICT and } \\
\text { Manual }\end{array}$} \\
\hline & & $\mathbf{F}$ & $* \%$ & $\mathbf{F}$ & $* \%$ & $\mathbf{F}$ & $* \%$ & $\mathbf{F}$ & $* \%$ \\
\hline 1 & Writing Minutes and / or reports $(n=85)$ & 5 & 5.9 & 72 & 84.7 & 0 & 0.0 & 8 & 9.4 \\
\hline 2 & Writing submissions $(\mathrm{n}=85)$ & 53 & 62.4 & 16 & 18.8 & 0 & 0.0 & 16 & 18.8 \\
\hline 3 & Treating Correspondences / Mails $(n=85)$ & 3 & 3.6 & 74 & 87.0 & 0 & 0.0 & 8 & 9.4 \\
\hline 4 & Writing replies to inquiries $(\mathrm{n}=85)$ & 42 & 49.4 & 14 & 16.5 & 0 & 0.0 & 29 & 34.1 \\
\hline 5 & Handling Student complaints $(n=50)$ & 35 & 70 & 8 & 16.0 & 0 & 0.0 & 7 & 14.0 \\
\hline 6 & Delivering seminars $(\mathrm{n}=50)$ & 33 & 66.0 & 9 & 18.0 & 6 & 12.0 & 2 & 4.0 \\
\hline 7 & Mentoring (up-stream) $(n=46)$ & 24 & 52.2 & 8 & 17.4 & 10 & 21.7 & 4 & 8.7 \\
\hline 8 & Mentoring (down-stream) $(n=46)$ & 17 & 37.0 & 18 & 39.1 & 7 & 15.2 & 4 & 8.7 \\
\hline 9 & Writing proposals $(\mathrm{n}=54)$ & 34 & 63.0 & 14 & 25.9 & 0 & 0.0 & 6 & 11.1 \\
\hline 10 & Management of teams or groups $(n=43)$ & 12 & 27.9 & 17 & 39.5 & 3 & 6.9 & 11 & 25.7 \\
\hline 11 & Committee Headship $(n=41)$ & 15 & 36.6 & 7 & 17.0 & 9 & 22.0 & 10 & 24.4 \\
\hline 12 & Committee "Secretary-ship" $(\mathrm{n}=63)$ & 30 & 47.6 & 19 & 31.2 & 0 & 0.0 & 14 & 22.2 \\
\hline 13 & $\begin{array}{l}\text { Provision of information to higher authority } \\
(\mathrm{n}=54)\end{array}$ & 26 & 48.1 & 5 & 9.3 & 10 & 18.5 & 13 & 24.1 \\
\hline 14 & $\begin{array}{l}\text { Generating / retrieving students' academic } \\
\text { records }(\mathrm{n}=40)\end{array}$ & 18 & 45.0 & 14 & 35.0 & 2 & 5.0 & 6 & 15.0 \\
\hline 15 & Processing staff recruitment $(\mathrm{n}=44)$ & 19 & 43.2 & 7 & 17.9 & 8 & 18.2 & 10 & 22.7 \\
\hline 16 & $\begin{array}{l}\text { Processing students' admission and / or } \\
\text { screening }(\mathrm{n}=38)\end{array}$ & 17 & 40.5 & 19 & 45.2 & 0 & 0.0 & 6 & 14.3 \\
\hline
\end{tabular}

Source: Field Survey *-total number of respondents differ for each of the above-listed variables due to the fact that not every Administrator is listed in tasks listed from numbers 5 - 16

The percentages reported above are valid percentages based on the actual number of respondents to whom the identified administrative tasks applied. ICT tools in the purview of this section included desktop computers, laptop computers, smart phones, tape recorders, batteries, projectors and screens for the hardware components. Software equipment included the use of Microsoft office suite, intranet facilities and internet facilities, among others.

Respondents also provided information that manual tools included pen, paper, file jackets and books / digests on administrative procedures. Verbal tools referred to the use of oral tradition in passing on instructions to subordinates or protégées and supplying information to colleagues and higher authorities.

It was interesting to note that although majority of the respondents were well-versed in the use of Microsoft Word processor, very few of them deployed this in the writing of minutes and / or reports. $84.7 \%$ of them still relied more on the use of pen and paper to take notes and thereafter did the typing themselves while a few handed them to a Secretarial Assistant (typist) for typing. This usually tended to delay final output because of the time taken in vetting and correcting. It is expected that Administrators, because of their heavy involvement in keeping records of meetings, would deploy their knowledge of ICT maximally in doing so. This would save the university 
a lot of material resources.

When it came to writing submissions, $62.4 \%$ made use of technology-based word processors in doing so. Writing submissions occur more frequently in the personnel-based units such as the Junior Staff Establishment and Welfare, Academic Staff Establishment and Administrative and Technical Staff Establishment. These units are involved in Staff recruitment, establishment, leave, discipline and exit matters.

Treating correspondences and mails is one of the daily functions of a university Career Administrator. The study revealed that very few (only 3.6\%) deployed the use of ICT in doing so. Majority depended on manual methods of file retrievals and use of pen and paper. This is attributed to the fact that the university is yet to fully operate an electronic administration system. Records of staff and students are not yet fully available online, although efforts are being made in this regard. This corroborates the findings of other studies by Adagunodo (2014) and Asahiah (2014).

Out of the $63.5 \%$ of the total sample population whose administrative duties included writing proposals, 34 persons, representing $63.0 \%$ made use of ICT applications in doing so. About $26 \%$ of them did so manually while $11 \%$ combined a variety of ICT and manual tools in writing proposals. The study therefore revealed that the administrative tasks that were performed with the highest level of ICT compliance were delivering seminars $(66.0 \%)$, writing proposals $(63.0 \%)$, writing submissions $(62.4 \%)$ and up-stream mentoring $(52.2 \%)$. The level of ICT compliance by Administrators in retrieving students' records was $45 \%$ while staff recruitment and student screening were rated $43 \%$ and $40 \%$ respectively. Furthermore, the study showed that the major administrative task that was performed manually was treating of correspondences and mails. This accounted for $87 \%$ of responses. The reasons adduced for this are that most of the University records are still in paper form and have to be accessed manually using relevant file jackets. Also, pen, paper and consultation with hard copy books and relevant official publications are mostly depended on as instruments of treating correspondences.

Objective 3: examine the attitude of Career Administrators at Obafemi Awolowo University to the adoption and usage of ICT tools to perform administrative tasks

Table 3: Frequency Distribution of Respondents according to attitude to adoption of ICT tools in the performance of administrative duties

\begin{tabular}{|c|c|c|c|c|c|c|c|c|}
\hline \multirow[t]{2}{*}{ Statement } & \multicolumn{2}{|c|}{$\begin{array}{r}\text { Affirmative } \\
\text { response }\end{array}$} & \multicolumn{2}{|c|}{$\begin{array}{l}\text { Negative } \\
\text { response }\end{array}$} & \multicolumn{2}{|c|}{$\begin{array}{r}\text { Undecided } \\
\text { response }\end{array}$} & \multicolumn{2}{|r|}{ Total } \\
\hline & $\mathbf{F}$ & $\%$ & $\mathbf{F}$ & $\%$ & $\mathbf{F}$ & $\%$ & $\mathbf{F}$ & $\%$ \\
\hline $\begin{array}{l}\text { The university has provided all ICT tools I } \\
\text { need to function effectively at work }\end{array}$ & 40 & 47.0 & 30 & 35.3 & 15 & 17.6 & 85 & 100.0 \\
\hline $\begin{array}{l}\text { I personally own all ICT facilities I need to } \\
\text { function effectively at work }\end{array}$ & 30 & 35.3 & 41 & 48.2 & 14 & 16.5 & 85 & 100.0 \\
\hline I prefer to type my work myself & 57 & 67.1 & 12 & 14.1 & 16 & 18.8 & 85 & 100.0 \\
\hline $\begin{array}{l}\text { I would rather have a typist do the typing of } \\
\text { my work - after all, that is why (s)he is } \\
\text { employed }\end{array}$ & 21 & 25.9 & 44 & 50.6 & 20 & 23.5 & 85 & 100.0 \\
\hline $\begin{array}{l}\text { It does not matter how long it takes to get my } \\
\text { minutes out - as long as it is eventually out }\end{array}$ & 16 & 18.8 & 60 & 70.6 & 9 & 10.6 & 85 & 100.0 \\
\hline $\begin{array}{l}\text { I have been commended several times for my } \\
\text { ability to generate minutes of meetings and } \\
\text { reports of committees speedily }\end{array}$ & 64 & 75.3 & 21 & 24.7 & 0 & 0.0 & 85 & 100.0 \\
\hline $\begin{array}{l}\text { I prefer to take notes of meetings with pen } \\
\text { and paper and thereafter give to a typist to } \\
\text { type or type myself }\end{array}$ & 39 & 45.7 & 35 & 41.3 & 11 & 13.0 & 85 & 100.0 \\
\hline I go to meetings with a laptop & 29 & 35.2 & 36 & 42.3 & 20 & 23.5 & 85 & 100.0 \\
\hline $\begin{array}{l}\text { When sending notices of meetings, I do so by } \\
\text { email and / or text messages }\end{array}$ & 54 & 63.6 & 24 & 28.2 & 7 & 8.2 & 85 & 100.0 \\
\hline $\begin{array}{l}\text { I prefer to send hard copies of notices of } \\
\text { minutes }\end{array}$ & 43 & 50.6 & 29 & 34.1 & 13 & 15.3 & 85 & 100.0 \\
\hline $\begin{array}{l}\text { It is difficult for me to send Minutes of } \\
\text { meetings online }\end{array}$ & 19 & 22.3 & 51 & 60.1 & 15 & 17.6 & 85 & 100.0 \\
\hline $\begin{array}{l}\text { I know how to vet soft copies of minutes and } \\
\text { /or reports using "track changes" in MS Word }\end{array}$ & 25 & 29.4 & 53 & 62.4 & 7 & 8.2 & 85 & 100.0 \\
\hline I need training to improve my ICT proficiency & 60 & 70.6 & 14 & 16.5 & 11 & 12.9 & 85 & 100.0 \\
\hline
\end{tabular}

Source: Field survey

The study examined the attitude of the respondents to the adoption of information and communication technologies in the discharge of their administrative duties using thirteen (13) variables on a 5-point LIKERT scale. 
Results showed that $47.0 \%$ of respondents were of the opinion that the University had provided all the ICT tools they needed to function in their capacity as Administrators. However, 35.3\% of the respondents disagreed with this position while the others were undecided. This implies that almost half of the respondents had a positive attitude towards the level of provision of necessary ICT tools by the University for their work. $67.1 \%$ of the respondents indicated the willingness, and consequently, a positive attitude towards typing their work by themselves rather than giving it to typists. More so, $70.6 \%$ of the respondents disagreed with the position that the length of time taken for minutes, reports and submissions to be generated does not actually matter, as long as they are eventually produced. These results point to a dissatisfaction with slow pace of work and desire for accelerated and accurate outputs. In the same vein, $75.3 \%$ of the respondents affirmed that they had been commended severally for getting their Minutes and reports ready within the time specified by the Manual of Administrative processes, confirming a positive attitude to the use of ICT to accelerate work processes and for accurate outputs. However, about $30 \%$ of the respondents stated that they did not know how to vet records in Microsoft Word using the "Track changes" menu and this was identified as a potential area for training in order to enhance speed and accuracy of administrative processes and records.

$35.2 \%$ of the respondents affirmed that they attended meetings with their laptops, either privately owned or provided by the University. The reason given by some of them was that they wanted to avoid as much as possible, delays in producing their outputs, which could inadvertently slow down decision making processes. This also attests to a positive attitude in the adoption of information and communication technologies for administrative processes. $63.3 \%$ of the respondents reported that they did not mind sending notices of meetings and other administrative information by electronic mail or text messages whenever the need arose. Others who responded in the negative stated that they would rather send hard copies because the latter could not be denied, whereas, it was possible for recipients of messages by electronic mail or text to feign ignorance about such information provided. Also, those in the latter category expressed the notion that the University was yet to formalize the process of sending electronic messages and make it official. They, therefore, did not feel safe to do so. $60.1 \%$ of the respondents disagreed with the position that it was difficult for them to send Minutes of meetings and reports online, thereby establishing that the internet was widely used among respondents as a veritable tool of communication, particularly in activities of committees. These findings are consistent with other studies (Nweze, 2010; Ojedokun and Owolabi, 2013; Adagunodo, 2014). 70.6\% of the respondents indicated a positive disposition and attitude towards training in order to enhance their ICT proficiency. The major areas of training identified were in the use of "track changes" menu (30\%), Microsoft Power Point (21.6\%), Microsoft Excel (8\%), Prezi (6\%) and Evernote (5\%).

Objective 4: identify the challenges militating against the deployment of information and communications technologies in administrative processes by Career Administrators at Obafemi Awolowo University

The study revealed that the major challenges militating against the maximal deployment of ICT tools by the respondents were epileptic power supply, unstable internet connectivity and the need to have to negotiate with other users of ICT hardware such as desktop, laptops and scanners in the workplace, before gaining access to such tools.

\section{Results of Data Generated through Interview Guide}

A structured Interview guide was administered on five (5) very senior Administrators to complement the data generated through the questionnaire. The interview guide posited twelve questions in all. All the respondents defined "Information Communication Technology" using key terms such as "applications", "enhance quality of output", "remove drudgery", "improve service delivery", "manage information in a timely and effective manner". The respondents believed that information and communication technologies had been widely accepted among academic and non-academic staff as well as among students.

With respect to the University having an ICT policy, responses were mainly to the effect that, although there was no written document about the compulsory digitization of administrative processes, several efforts in making the computerization of service delivery units had been observed in the last five (5) years. Training on ICT matters was ad-hoc and not well-defined or properly structured. Respondents recalled that members of staff had the opportunity of enrolling for the University's Electronic Data Processing (EDP) programme or Diploma in Computer Training (DCT) programme but these programmes were not really effective as they were more theoretical than practical.

All the respondents confirmed having access to official username and password, desktop computers, flash drives and printers in their offices. $40 \%$ owned personal laptop computers. Furthermore, they mentioned the photocopying machine as one of the tools that they used regularly. Also, all the respondents were able to use the Microsoft Word application confidently.

\section{Major Findings}

The study was an enquiry into the usage of information and communication technologies by professional or career 
Administrators in Obafemi Awolowo University, Ile-Ife. This population was targeted at mainly because of the critical roles they play as custodians of University records and drivers of the administrative processes in faculties, departments and other service centres or units in the university. The objectives of the study were to identify the information and communication technology tools used by career administrators in Obafemi Awolowo University, Ile-Ife; determine the level of ICT compliance in the performance of administrative tasks by the career administrators in the said institution; examine the attitude of the respondents to the adoption and use of information and communication technologies in performing administrative tasks; and identify the challenges militating against the optimal deployment of ICTs by career administrators in the study area.

Using a simple random sampling technique, eighty five (85) respondents were selected from a population size of one hundred and four (104) professional Administrators spanning from Administrative Officers II all through to Directors / Acting Directors in charge of administrative processes in the University to generate primary data. This was complemented by results obtained from the interview of five (5) other respondents using a structured guide. Secondary data were obtained from relevant university books and digests, previous published and unpublished studies related to the use of ICT in different sectors of national life, official documents and internet sources on ICT. The data collected were analysed using the standard Statistical Package for Social Science research (SPSS) to generate frequency distribution, simple percentages and bar charts. Further tests to determine association of key variables with factors such as access to ICT tools, ownership of ICT tools and use of ICT software by respondents were carried out and measured by chi-square values.

Male and female respondents represented $56.5 \%$ and $43.5 \%$ of the sample population respectively. $95.3 \%$ were aged between 31 and 60 and were thus in their peak productive years. The study showed that there was adequate access to basic ICT hardware in the workplace such as desktop computers (85.8\%) and printers (77.6). $75.3 \%$ of the respondents had smart phones which were enabled to perform some administrative functions such as sending and receiving electronic mail, notices of meeting, committee assignment chat groups, etc. $92.9 \%$ of the respondents were able to use Microsoft word while only $1.2 \%$ each were able to deploy the use of Prezi and Evernote in providing administrative services.

Results also showed that about $93 \%$ of the respondents were able to use Microsoft Word in varying degrees. On the other hand, the percentages of those who were able to use Microsoft Excel and Microsoft Power point were $14.2 \%$ and $11.8 \%$ respectively while only $1.2 \%$ had the ability to use Prezi and Evernote applications. By implication, Career Administrators at Obafemi Awolowo University were most proficient in word processing applications while they were largely deficient in the use of spreadsheet and data base applications. The study further revealed that Microsoft Word was the most used ICT software and that a strong association was found to exist between access to ICT and job rank of respondents with more highly ranked Administrators having higher access to ICT facilities ( $\mathrm{p}$ value $=0.001 ; \mathrm{df}=6$ ).

The major challenges militating against the maximal deployment of ICT tools by the respondents are epileptic power supply, unstable internet connectivity and the need to have to negotiate with other users of ICT hardware such as desktop, laptops and scanners in the workplace, before gaining access to such tools.

\section{Conclusion and Recommendations}

Arising from the findings of this study which are drawn from the analysis of the data obtained in the course of the field work, certain conclusions have emerged. Information Communication Technologies (ICTs) have been deployed to support and enhance the administrative processes in terms of speed and accuracy as well as the management of information in Obafemi Awolowo University, Ile-Ife. This has given rise to quicker and more accurate decision making processes, improved service delivery, faster communication, ease of collaboration and improved coordination, efficiency and effectiveness, accuracy and timeliness.

The study concluded that information and communication technologies have been widely embraced by career Administrators in the University and this has, to a large extent, improved effectiveness, accuracy and efficiency in the area of service delivery. However, there was need for further training especially with regards to the use of advanced features such as "track changes" in Microsoft Word as well as Power Point, Prezi, Evernote and Microsoft Access for improved administrative services in the University.

Based on the research findings and deductions made from this study, the following recommendations are suggested:

(1) Higher Education Institutions should have a clear cut policy statement on the use of information and communications technology in their processes so that members of staff can embrace it fully.

(2) Higher Education Institutions should improve on the capacity building of their staff through regular training and retraining. In order to ensure effectiveness, it is recommended that the training modules be customized to fit into the areas of deficiencies of the members of staff who are expected to improve the overall quality of the university administrative processes. For instance, a member of staff who is already versatile in the use of Microsoft Word but deficient in using Microsoft Access should be exposed to the latter and excused from training on the former to enhance efficiency. 
(3) It is recommended that every officer should be able to access both software and hardware to be deployed in the performance of their administrative tasks without having to negotiate with others.

\section{REFERENCES}

Adagunodo, O. D (2014) A Study of E-Administration in Obafemi Awolowo University, Ile-Ife, Nigeria. A Long Essay submitted to the Department of Public Administration, Obafemi Awolowo University, Ile-Ife, for the award of a Master of Public Administration Degree

Asahiah, A. O (2014) A Study of E-Administration in Obafemi Awolowo University, Ile-Ife, Nigeria. A Long Essay submitted to the Department of Public Administration, Obafemi Awolowo University, Ile-Ife, for the award of a Master of Public Administration Degree

Bello, O. A and F. M. Aderibigbe (2014) The Role of ICT in National Development. IMPACT: International Journal of Research in Engineering and Technology (IMPACT: IJRET). ISSN(E): 2321-8843; ISSN(P): 2347-4599. Vol. 2, Issue 5, May 2014, 275-284 (C) Impact Journals

Breach, E. F. L. (1975) The Principles and Practice of Management. New York: Longman Publishers

FGN (2012) Four-Year Strategic Plan for the Development of the Education Sector: 2011 - 2015. Nigeria: Federal Ministry of Education

Nweze, C. M. (2010) The use of ICT in Nigerian Universities: A Case Study of Obafemi Awolowo University, Ile-Ife. Library Philosophy and Practice (e-journal). Paper 494

OAU (2008) Obafemi Awolowo University Book Calendar (2008 - 2012) Obafemi Awolowo University Publishing Press Ltd.

OAU (2011) Obafemi Awolowo University Strategic Plan (2011 - 2015). Ile-Ife: Obafemi Awolowo University Publishing Press Ltd.

Ogunruku, A. O. (2012) University Administration in the $21^{\text {st }}$ Century: A new direction. Ile-Ife: Obafemi Awolowo University Publishing Press Ltd.

Ojedokun, A.A and E. O. Owolabi (2003) Internet use for Teaching and Research in Botswana. African Journal of Library, Archives and Information Science, 13(1):43-53.

Popoola, Femi (2013) Effects of Challenges of Information Communication Technologies (ICT) on Information Management at The University College Hospital (UCH) Ibadan, Nigeria in Quarterly Journal of Administration, Obafemi Awolowo University, Ile-Ife, Nigeria, Vol. XXXIII (2): 189-204.

Salerno, C. (2009) Administrator's Role in Technology Integration. Educational World 2009

Usluel, Y. K; P. Askar and T. Bas (2008) A Structural Equation Model for ICT Usage in Higher Educational Institutions. Educational Technology and Society. Vol. 11 (1): pp 262 - 273

\section{Internet Sources}

About Prezi http://en.m.wikipedia.org/prezi. Accessed on $27^{\text {th }}$ August, 2015

A Brief History of Microsoft Access www.brighthub.com/office/collaboration/tools. Accessed on 27th August, 2015

A Brief History of Microsoft PowerPoint www.brighthub.com/office/collaboration/tools. Accessed on 27th August, 2015

Hafkin, N. (2002) Gender issues in ICT policy in developing countries: An overview. Paper presented at the $U N$ Division for the Advancement of Women Expert Group Meeting on Information and Communication Technologies and Their Impact On and Use as an Instrument for the Advancement and Empowerment of Women, Seoul, Republic of Korea, 11-14 November 2002. Available at:

http://www.un.org/womenwatch/daw/egm/ict2002/reports/Paper-NHafkin.PDF. Accessed on 10th August, 2015

History of Microsoft Excel. http://en.m.wikipedia.org/microsoftword. Accessed on 27 ${ }^{\text {th }}$ August, 2015

History of Microsoft Word. http://en.m.wikipedia.org/microsoftword. Accessed on 27 $7^{\text {th }}$ August, 2015

UNESCO (2000) United Nations Economic and Social Council. Para. 6. Accessed on 23 ${ }^{\text {rd }}$ August, 2015

United Nations (2000) General Assembly Special Session (UNGASS) to review the status of the Beijing Platform for Action 2000. In: Hafkin, N. and Taggart, N. Gender, information technology, and developing countries: an analytic study, for the Office of Women in Development Bureau for Global Programs, Field Support and Research, United States Agency for International Development (USAID). Available at: http://www.usaid.gov/wid/pubs/hafnoph.pdf (Accessed: $5^{\text {th }}$ September, 2015).

UN (2002) United Nations Information and Technology Task Force. Para 2. Accessed on $23^{\text {rd }}$ August, 2015 